\title{
Порівняльний аналіз державних банків розвитку Індії та Китаю
}

\author{
(Представлено: д.е.н., проф. Н.Г. Виговська)
}

Економічні системи найбільших країн світу побудовані на взаємодії публічного (державного) та приватного секторів. Банки, що перебувають у державній власності, спрямовані на подолання «провалів» ринку заради загального економічного зростання. У регіоні Південної Азї державний сектор у національній банківській системі відіграє вирішальну роль. Найбільші масштаби операчій характеризують державні банки Індї та Китаю, зокрема, банки розвитку. В той же час, моделі бізнесу таких банків різняться, щзо обумовлено різним рівнем централізації та втручання держави в економіку. Можна стверджувати, що державні банки розвитку (далі ДБР) є потужним інструментом економічної політики, щзо досить успішно використовується для антициклічного регулювання та усунення галузевих і регіональних диспропориій. Оиінювати ефективність діяльності ДБР необхідно не стільки за традиційним набором показників рентабельності $і$ якості активів, а темпами приросту валового національного продукту, забезпеченням зайнятості, позитивного балансу зовнішньої торгівлі, рівнем начіонального добробуту краӥн, в яких вони знаходяться. Узагальнення моделей функиіювання ДБР вкрай важливе для Украӥни, яка потребує стимулювання економічного зростання $i$ зменшення залежності від зовнішнього кредитного фінансування. Вибір Індї та Китаю для дослідження обумовлений схожістю економік ичих країн.

Ключові слова: банківській сектор; економічне зростання; банк розвитку; модель бізнесу; державна власність; партнерство держави та бізнесу.

Вступ. Економічні системи найбільших країн світу побудовані на взаємодії публічного (державного) та приватного секторів. Банки, що перебувають у державній власності, спрямовані на подолання «провалів» ринку заради загального економічного зростання. В регіоні Південної Азії державний сектор у національній банківській системі відіграє вирішальну роль. Найбільші масштаби операцій характеризують державні банки Індії та Китаю, зокрема банки розвитку. Оцінювати ефективність діяльності ДБР необхідно не стільки за традиційним набором показників рентабельності і якості активів, а темпами приросту валового національного продукту, забезпеченням зайнятості, позитивного балансу зовнішньої торгівлі, рівнем національного добробуту країн, в яких вони знаходяться. Узагальнення моделей функціювання ДБР вкрай важливе для України, яка потребує стимулювання економічного зростання і зменшення залежності від зовнішнього кредитного фінансування. Вибір Індії та Китаю для дослідження обумовлений схожістю економік цих країн і вираженим політичним курсом на економічний націоналізм.

Аналіз досліджень та публікацій. Державним банкам розвитку присвячені численні фундаментальні дослідження зарубіжних економістів, що обумовлено не тільки масштабами діяльності цих фінансових установ, але й оцінкою їх впливу на економіку, економічну конкуренцію на національному і міжнародному рівнях, створення механізмів балансування економічних інтересів. Слід підкреслити вагомий науковий внесок експертів міжнародних фінансових організацій.

Зокрема, Світовий банк у 2012 та 2017 роках проводив опитування національних банків розвитку (вибірка враховувала установи за критеріями частки держави у капіталі не менше 30 відсотків і стратегією досягнення соціально-економічних цілей) [1-5] та встановив, що ДБР здатні сприяти подоланню турбулентності на фінансових ринках, у коротко- та середньостроковій перспективі уряди країн мають вагомі причини продовжувати модернізувати свої БД та надавати їм інструменти для підвищення ефективності у виконанні своїх політичних мандатів. Експерти Міжамериканського банку розвитку дійшли до висновку, що національні банки розвитку можуть відігравати унікальну роль у збільшенні приватного фінансування проєктів з пом'якшення кліматичних змін на відповідних місцевих ринках кредитування та умов, що необхідні для того, щоб вони були найбільш ефективними [6]. Група вчених 3 Китаю та Аргентини виявила, що облігації ДБР мають більшу вартість, ніж облігації, випущені комерційними банками, дозволяючи державним банкам краще впоратися з ризиками невідповідності строків погашення та проблемами з ліквідністю. Перебування у державній власності означає, що акціонери мають більшу готовність і спроможність додатково капіталізувати банки порівняно 3 власниками приватних банків [4].

Вітчизняні економісти характеризують моделі бізнесу державних банків, їх роль у кредитуванні реального сектору економіки [7-9]. Увага українських вчених приділяється в основному загальним 
аспектам функціонування банків, які перебувають у державній власності, без виокремлення моделі банку розвитку. Виокремимо публікації В.В. Огородник, яка факторами ефективного розвитку державних банків вважає їх орієнтацію на комерційну ефективність, поєднання приватного та державного капіталу у статутному капіталі банків, незалежність наглядових рад банків від політичного впливу та впровадження ефективних моделей стратегічного управління [10].

Ухвалена загальна стратегія реформування державних банків не передбачає створення повноцінного банку розвитку в Україні [11], незважаючи на наявність чотирьох великих державних банків зі схожою моделлю бізнесу (варто зазначити, що офіційний текст стратегічного документа відсутній на офіційному сайті Уряду України). Національний банк України, Національна комісія з цінних паперів та фондового ринку, Національна комісія, що здійснює державне регулювання у сфері ринків фінансових послуг, Міністерство фінансів України та Фонд гарантування вкладів фізичних осіб затвердили Стратегію розвитку фінансового сектору України до 2025 року, без намірів створити державний банк розвитку [12].

Постановка завдання полягає у проведенні порівняльного аналізу діяльності ДБР Китаю та Індії 3 метою визначення загальних рис і національних особливостей.

Результати дослідження. Державні банки розвитку (далі - ДБР) є потужним інструментом економічної політики, що досить успішно використовується для антициклічного регулювання та усунення галузевих і регіональних диспропорцій. 3 часу фінансової кризи 2007-2009 років зростає інтерес науковців до розуміння того, як працюють такі банки розвитку, яка їх основна мета, які інструменти, стимули та управління є найкращими в цілому та у конкретному контексті та які їх зв'язки 3 приватним фінансовим i корпоративним сектором, а також із загальною державною політикою.

Державний (національний) банк розвитку є установою, що виконує функцію стимулювання економічного і соціального розвитку країни, перебуваючи у володінні та під контролем держави (уряду). Держава визначає стратегію бізнесу та призначає органи вищого керівництва ДБР [4]. Різниця в моделях бізнесу обумовлена різним рівнем централізації та втручання держави в економіку. Опитування ДБР світу, проведене Світовим банком у 2017 році, показало що уряди використовують їх для надання фінансових послуг у секторах чи регіонах, де приватні фінансові посередники не працюють належним чином [1]. Нові ДБР продовжують створюватися в країнах, що розвиваються, та в розвинених країнах, для поліпшення інфраструктури, екології та взагалі мобілізації додаткового фінансування для досягнення широкого кола цілей розвитку. Четверта частина з обстежених Світовим банком (45 ДБР) була створена за останні 18 років, зокрема у Канаді, Анголі, Гані та М'янмі. ДБР значно різняться з точки зору їх розміру, фінансових результатів, цілей розвитку, бізнес-моделей, механізмів фінансування та практики управління. Більшість ДБР обслуговує приватний сектор, зокрема, 87 \% установ в першу чергу спрямовані на малі та середні підприємства, 78 \% обслуговують великі приватні корпорації, а 64 \% - приватні фінансові посередники, які позичають кошти у ДБР для наступного кредитування кінцевих позичальників або використовують гарантії, які видають БД для зменшення кредитного ризику у кредитуванні.

Індія становить особливий інтерес, оскільки в цій країні у 1980-1990 роках відбувся по суті масштабний експеримент зі створенням інституцій розвитку, що враховував державні банки та фінансовоінвестиційні корпорації для підтримки галузей енергетики і суднобудування. Індія була піонером у період після Другої світової війни, адже в цій країні було створено одразу кілька фінансових установ, які можуть вважатися за статусом ДБР. Вони були створені для запуску процесу індустріалізації шляхом довгострокових кредитів для приватних інвестицій у промисловість за рахунок коштів держави:

- Індійська корпорація фінансування Індії (IFCI, 1948 рік),

- Промислова кредитно-інвестиційна корпорація Індії (ICICI, 1955 рік) та

- Банк промислового розвитку Індії (IDBI, 1964 рік).

Також були створені інвестиційні установи: Life Insurance Corporation (страхування життя) у 1964 році, General Insurance Corporation of India (загальне страхування) у 1973 році та державні фінансові корпорації (ДФК). Зазначені корпорації мобілізували заощадження домогосподарств та поширювали традиції страхування. Деякі з них підтримували також початковий бізнес та інновації у сфері послуг. У ДФК були свої недоліки: недосконалий аналіз кредитних проєктів, портфель не містить інфраструктурних проєктів, відсутня координація між кредитуванням та розвитком реального сектору, а головне, що приріст кредитів супроводжувався погіршенням їх якості.

Показово, що промислова кредитно-інвестиційна корпорація Індії (ICICI) розпочинала 3 довгострокового валютного кредиту Світового банку. Національний промисловий кредитний фонд заснував Резервний банк Індії саме для довгострокового фінансування. У результаті у 1980-х роках в Індії існували три банки розвитку і вісімнадцять ДФК. Крім того, у 1990 році держава створила Банк розвитку малого бізнесу (SIDBI) для підтримки малого та середнього бізнесу. Національний банк аграрного та сільського розвитку (NABARD) був створений у 1998 році.

Криза платіжного балансу в Індії у 1990-х роках призвела до початку фінансової лібералізації та перегляду ставлення до пільгового фондування державних установ розвитку. Приватні фінансові установи не мали доступу до таких ресурсів, що порушувало правила справедливої конкуренції і не створювало 
стимули для приходу нових учасників ринку. Зміна курсу проявилася у трансформації ICICI (у 2002 році) та IDBI (у 2004 році) із унітарних в комерційні банки за участі держави. Подальша лібералізація проявилася у законодавчій зміні статусу корпорації IFCI на акціонерне товариство, від якого вже вимагалося залучати ресурси не у держави, а на відкритому ринку. Нішу спеціалізованих установ, які могли б надавати довгострокові кредити, поступово заповнювали звичайні комерційні банки, частка яких у кредитуванні інфраструктури зросла з 5 \% у 1998 році до 32 \% у 2012 році Враховуючи, що приватні банки формували ресурсну базу за рахунок короткострокових депозитів, кредитування інфраструктурних проєктів призвело до значних дисбалансів ліквідності, а згодом збільшення проблемних кредитів погіршило фінансовий стан банківського сектору. Комерційні банки не мали можливості оцінювати кредитний ризик за довгостроковим інвестиційним кредитуванням, оскільки вони завжди брали участь у просуванні короткострокових оборотних коштів.

У Китаї держава створила у 1994 році China Development Bank (CDB), але незабаром він опинився на межі банкрутства, все ж таки його роботу відновили на початку 2000-х років.

CDB у межах китайської стратегії глобального просування надає позики іноземним урядам з початку 2000-х років. У деяких країнах Латинської Америки і Африки СDВ часто є найбільшим джерелом фінансування банків розвитку. CDB залучає фондування не через приватні депозити, а шляхом випуску облігацій на термін до 30 років для придбання інституціональними інвесторами на місцевому ринку Китаю і на зарубіжних ринках як в юанях, так і в інших валютах. Це другий за величиною емітент облігацій в Китаї після міністерства фінансів, і його облігації мають кредитний рейтинг, еквівалентний державним облігаціям. Китайська держава опосередковано гарантує його борг, що дозволяє СDВ здешевлювати ресурсну базу і надавати більш довгострокові кредити, ніж інші китайські банки. CDB також $є$ найбільшим китайським кредитором в іноземній валюті, спираючись безпосередньо на великі валютні резерви Китаю.

Зараз, із загальними активами в 1,85 трлн дол. США, СDB належить до найбільших та найдинамічніших національних банків розвитку у світі. CDB $є$ ключовим фактором у створенні адекватної системи кредитування місцевого самоврядування та сприяє побудові інфраструктури.

Особлива роль ДБР проявилася у період боротьби з коронавірусом. Китайський банк розвитку виділив 2 млрд юанів на екстрені позики провінції Ухань для боротьби з коронавірусом. 28 лютого 2020 року Міністерство торгівлі та Банк розвитку Китаю спільно видали Циркуляр про використання фінансів розвитку для підтримки шляхового господарства, а також підприємств, постраждалих від епідемії, в якому вказано про:

- $\quad$ надання дешевих позик (в межах 30 базових пунктів) для поповнення обігових коштів;

- $\quad$ надання позик у місцевій та іноземній валюті, в т. ч. в іноземній валюті на суму 5 млрд дол. США для відновлення роботи;

- подовження строків погашення позики;

- прискорення кредитування підприємств, постраждалих від епідемії;

- надання диверсифікованої фінансової підтримки (наприклад, посилення координації 3 закордонними фінансовими установами та сприяння гнучкому й диверсифікованому сервісу фінансування національної та іноземної валюти).

Заходи були введені для захисту цілісності інфраструктурних проєктів, які вже реалізуються, та проєктів, що терміново впливають на економіку та мають вирішальне стратегічне значення.

Висновки. Створення державного банку розвитку доведено історичним досвідом відновлення національних економік після криз. Великі країни створюють різні за профілем банки розвитку, але з акцентом на довгострокових проєктах з фінансування інфраструктури і окремо малого та середнього бізнесу. Ресурсна база китайських та індійських банків спочатку формувалася за рахунок державних фінансувань, проте згодом ДБР успішно вийшли на ринки запозичень. На відміну від КНР, державний банк розвитку отримав для старту ще довгострокове кредитування від міжнародної фінансової організації. Для України досвід банків розвитку важливий в плані уникнення помилок у виборі моделі бізнесу та пошуку ресурсів для фінансування проєктів. Враховуючи наявність в Україні державних банків зі схожим профілем ресурсної бази та кредитноінвестиційною політикою, доречно не створювати заново ДБР, а перепрофілювати два державні банки на спеціалізацію з фінансування інфраструктури та окремо - для підтримки інновацій малого бізнесу. Ресурсна база таких банків може бути зміцнена на першій фазі за рахунок цільового фінансування міжнародних фінансових організацій (навіть у межах існуючих лімітів) з подальшим залученням іноземних інвесторів і виходом на IPO зі збереженням контрольної частки держави у капіталі.

\section{Список використаної літератури:}

1. 2017 survey of national development banks // The World Bank Group [Електронний ресурс]. - Режим доступу : http://documents.worldbank.org/curated/en/977821525438071799/2017-Survey-of-National-development-banks.

2. Chandrasekhar C. National development banks in a comparative perspective / C.Chandrasekhar; ed. A.Calcagno. and other // Rethinking Development Strategies after the Financial Crisis: Volume II Country Studies and International Comparisons. - New York : UN, 2016 [Електронний ресурс]. - Режим доступу : https://doi.org/10.18356/8c01d4b6en. 
3. Griffith Jones Stephany The Future of National Development Banks / Griffith Jones Stephany, Ocampo José Antonio. - Oxford University Press, 2017.

4. LunaMartínez J. Global Survey of Development Banks / J. de LunaMartínez, C.L. Vicente // The World Bank Group. Policy Research Paper 5969. 2022 [Електронний ресурс]. - Режим доступу : https://elibrary.worldbank.org/doi/pdf/10.1596/181394505969.

5. Schclarek A. The Maturity Lengthening Role of National Development Banks / A.Schclarek, J.Xu, J.Yan. - May 2020 [Електронний ресурc]. - Режим доступу : http://www.ssmsc.gov.ua/activities/corpmanagement.

6. The Role of National Development Banks in Catalyzing International Climate Finance / D.Smallridge, B.Buchner, C.Trabacchi and other // InterAmerican Development Bank. - March 2013 [Електронний ресурс]. - Режим доступу : https://publications.iadb.org/en/rolenationaldevelopmentbankscatalyzinginternationalclimatefinance.

7. Дробязко А.О. Роль банків за участю держави в капіталі у розвитку реального сектору економіки України / А.О. Дробязко, С.Б. Беспалий // Фінанси України. - 2018. - № 11. - С. 76-105.

8. Костогриз В.Г. Державні банки у системі забезпечення фінансової стабільності банківського сектору України / В.Г. Костогриз, М.Е. Хуторна // Науковий вісник Ужгородського університету. Серія : Економіка. 2018. - Вип. 1. - С. 335-341 [Електронний ресурс]. - Режим доступу : http://nbuv.gov.ua/UJRN/Nvuuec_2018_1_56.

9. Любіч О.О. Аналіз бізнес-моделі державних банків в Україні / О.О. Любіч, Г.П. Бортніков, Г.О. Панасенко // Фінанси України. - 2016. - № 10. - С. 7-38.

10. Огородник B.B. Банки 3 державною участю в Україні: теорія, методологія та практика : монографія / В.В. Огородник. - Київ : ДВНЗ «Університет банківської справи», 2019. - 319 с.

11. Оновлені «Засади стратегічного реформування державного банківського сектору», підтримані Урядом 21.02.2018 p. [Електронний ресурс]. - Режим доступу : https://www.kmu.gov.ua/ua/news/.

12. Регулятори фінансового ринку затвердили Стратегію розвитку фінансового сектору України до 2025 року / Національний банк України. - 16 січ. 2020 p. [Електронний ресурс]. - Режим доступу : https://bank.gov.ua/ua/news/all/strategiyarozvitkufinansovogosektoruukrayinido2025roku7686.

\section{References:}

1. The World Bank Group (2017), 2017 survey of national development banks, [Online], available at: http://documents.worldbank.org/curated/en/ 977821525438071799/2017-Survey-of-National-development-banks

2. Chandrasekhar, C. (2016), «National development banks in a comparative perspective», in Calcagno, A. et al. (ed.), Rethinking Development Strategies after the Financial Crisis: Volume II Country Studies and International Comparisons, UN, New York, 2016, [Online], available at: https://doi.org/10.18356/8c01d4b6en

3. Griffith, Jones Stephany and Ocampo, José Antonio (2017), «The Future of National Development Banks», Oxford University Press.

4. LunaMartínez, J. de and Vicente, C.L., «Global Survey of Development Banks», The World Bank Group. Policy Research Paper 5969. 2022, [Online], available at: https://elibrary.worldbank.org/doi/pdf/10.1596/181394505969

5. Schclarek, A., Xu, J. and Yan, J. (2020), The Maturity Lengthening Role of National Development Banks, May, [Online], available at: http://www.ssmsc.gov.ua/activities/corpmanagement

6. Smallridge, D., Buchner, B., Trabacchi, C. et al. (2013), «The Role of National Development Banks in Catalyzing International Climate Finance», InterAmerican Development Bank, March, [Online], available at: https://publications.iadb.org/en/rolenationaldevelopmentbankscatalyzinginternationalclimatefinance

7. Drobjazko, A.O. and Bespalyj, S.B. (2018), «Rol' bankiv za uchastju derzhavy v kapitali u rozvytku real'nogo sektoru ekonomiky Ukrai'ny», Finansy Ukrai'ny, No. 11, pp. 76-105.

8. Kostogryz, V.G. and Hutorna, M.E. (2018), «Derzhavni banky u systemi zabezpechennja finansovoi' stabil'nosti bankivs'kogo sektoru Ukrai'ny», Naukovyj visnyk Uzhgorods'kogo universytetu, Serija Ekonomika, Issue 1, pp. 335341, [Online], available at: http://nbuv.gov.ua/UJRN/Nvuuec_2018_1_56

9. Ljubich, O.O., Bortnikov, G.P. and Panasenko, G.O. (2016), «Analiz biznes-modeli derzhavnyh bankiv v Ukrai'ni», Finansy Ukrai'ny, No. 10, pp. 7-38.

10. Ogorodnyk, V.V. (2019), Banky z derzhavnoju uchastju v Ukrai'ni: teorija, metodologija ta praktyka, monografija, DVNZ «Universytet bankivs'koi' spravy», Kyi'v, 319 p.

11. Onovleni «Zasady strategichnogo reformuvannja derzhavnogo bankivs'kogo sektoru», pidtrymani Urjadom 21.02.2018 r., [Online], available at: https://www.kmu.gov.ua/ua/news/

12. Nacional'nyj bank Ukrai'ny (2020), Reguljatory finansovogo rynku zatverdyly Strategiju rozvytku finansovogo sektoru Ukrai'ny do 2025 roku, 16 sich., [Online], available at: https://bank.gov.ua/ua/news/all/strategiyarozvitkufinansovogosektoruukrayinido2025roku7686

Свистун Андрій Олександрович - начальник відділу з питань участі держави у капіталізації банків, Міністерство фінансів України.

Наукові інтереси:

- теоретичні засади функціонування державних банків розвитку.

https://orcid.org/0000000321852248.

E-mail: svalm777@ukr.net. 